\title{
EFFECT OF PLEUROTUS TUBERREGIUM SCLEROTIUM ON CHEMICAL, ANTIMICROBIAL AND SENSORY PROPERTIES OF PACKAGED TOMATO PASTE
}

\author{
*Kolawole, F.L., Balogun, M.A., Karim, O.R., Muhammad, A.O. and Sanni- \\ Olayiwola, H.O. \\ Department of Home Economics and Food Science, University of Ilorin, \\ Kwara state.
}

*Corresponding Author: Kolawole.fl@unilorin.edu.ng

\begin{abstract}
Tomato (Solanum lycopersicum) is one of the most widely consumed fresh vegetables in the world. Due to its low shelf-life, it is processed into paste with added chemical preservatives. Pleurotus tuberregium (P.t.s) is a good source of bioactive compounds effective against microbial growth, in addition to its load of other nutrients. In this study, the physicochemical, microbial, antioxidant activity and sensory properties of packaged tomato paste supplemented with Pleurotus tuberregium sclerotium flour were investigated using standard methods. The tomato pastes and Pleurotus tuberregium sclerotium flour were mixed in ratios of 100:0, 95:5 and 90:10 after which they were stored in low-density polyethylene and plastic containers at ambient temperature. There was a haphazard decrease in the fungal count of the supplemented samples during storage. A progressive increase in antioxidant activity at different inhibition levels was observed, with the samples packaged in plastic having the highest value at $100 \mathrm{mg} / \mathrm{ml}$ titration. The DPPH value range obtained for (Day 0), (Day 4) and (Day7) were 4.7 - 49.9\%, $50.2-53.8 \%$ and $50.0 \%-52.2 \%$, respectively. A slight decrease in vitamins and minerals composition of treated samples as compared to the control was evident after storage period. Moderate addition of 5 to $10 \%$ Pleurotus tuberregium sclerotium flour is effective in improving the physicochemical properties, vitamins and minerals content, antioxidant activity, sensory properties and microbial stability of the paste stored in plastic container.
\end{abstract}

Keywords: Tomato paste, Pleurotus tuberregium sclerotium, low density polyethylene, plastic container, chemical composition 


\section{INTRODUCTION}

Tomato (Solanum lycopersicum) is a widely consumed fruit for nutritional and culinary purposes. It is an important source of vitamins and minerals such as vitamins $\mathrm{A}, \mathrm{C}$ and $\mathrm{E}$, and calcium, potassium, and phosphorus (Correia et al., 2015). It also contains health promoting phenolic compounds, pigments and other antioxidants (Silva-Beltran et al., 2015). Tomato paste is an intended product for preserving fresh tomatoes and making them available in another variety for consumption. It is known for its convenience, easy access for culinary purpose and has a longer shelf-life than fresh tomatoes. Chemical preservatives are thus used to preserve commercial tomato paste but some of these preservatives have been associated with some adverse health issues in different test systems (Turkoglu, 2007). Pleurotus tuberregium (the sclerotia- producing mushroom) is a tropical mushroom that produces the edible sclerotium or an underground tuber as well as the mushroom fruiting body (Iwuagwu and Onyekweli, 2002). It has been reported that the sclerotia of Pleurotus tuberregium (Fries) Singer is a good source of minerals (Magnesium, Sodium, Calcium, Potassium and Iron) as well as bioactive compounds effective against microbial growth (Ikewuchi and Ikewuchi, 2010). The methanolic and aqueous extracts from Pleurotus tuberregium sclerotium $(P, t . \mathrm{s})$ have been found to be effective against some bacteria strains (Anyawu et al., 2016). These nutritional and antimicrobial properties of Pleurotus tuberregium remain under exploited in the production of foods. Tomato paste especially, is a commonly consumed product in households and the inclusion of Pleurotus tuberregium could be an easy means of incorporating important nutrients such as bioactive glucans in the diets of people and as well serve as a bio preservative. However, at home levels, pastes made from vegetables and pastes are prone or susceptible to microbial spoilage and chemical disintegration. Food flours are versatile and could be easily produced and incorporated into different products. Therefore, this study aims to evaluate the effect of Pleurotus tuberregium sclerotium flour addition on the chemical, antimicrobial and sensory properties of packaged tomato paste.

\section{MATERIALS AND METHODS}

Tomatoes and Pleurotus tuberregium sclerotium (P.t.s) were sourced from a local market in Ilorin, Kwara State, Nigeria. The tomato paste was processed using the method described by Iwe (2002) with slight modification. Briefly, the fresh tomatoes were washed, blanched for three minutes and cooled by submerging in cold water. The skin was peeled off and the seed cavity was removed and then pulped in a blender. The pulp was heated in an open pot at $100^{\circ} \mathrm{C}$ for 45 minutes to concentrate the paste. P.t.s was peeled, sliced and milled into flour using a locally fabricated milling machine. 


\section{Formulation of Tomato Paste}

Three samples were produced from tomato paste and Pleurotus tuberregium sclerotium in the following proportions; 100/0; 95/5 and 90/10. The samples were then packaged in sterilized low-density polyethylene and plastic containers at ambient temperature for further studies while the control sample was subjected to analyses immediately.

\section{Analyses}

Moisture content was determined using the method of moisture determination as described by Association of Official Analytical Chemist (1990). pH determination was carried out using pH meter (Jenway 3505, Bibby Scientific, London, UK). The total acidity was determined according to AOAC (2005) official method. The viscosity of the samples was determined using Ostwald viscometer. Ascorbic acid was estimated by the method of AOAC (2005). Spectrophotometer (Jenway 7305, Bibby Scientific, London, UK) was used for determination of vitamin A. The spectrophotometer was set up to a wavelength of $436 \mathrm{~nm}$ and cuvette- containing pet-ether (blank) was used to calibrate to zero point. After the concentration of alpha-carotene was calculated, the vitamin A (Retinol) was calculated by using the following: $6 \mu \mathrm{g}$ of alphacarotene is equivalent to $1 \mu \mathrm{g}$ of retinol equivalent. Antioxidant activity was determined using DPPH Radical scavenging Assay (Liyana-Pathiranan and Shahidi, 2005).

\section{Microbiological Analysis of Tomato Paste}

Qualitative bacteriological analysis of the samples was carried out using total plate count on nutrient agar (NA) while fungi isolation was also done using potato dextrose agar (PDA). The counts were expressed in cfu/ml. Total microbial counts of the samples were determined every $48 \mathrm{hr}$ till the last stage (Balogun et al., 2015).

\section{Sensory Evaluation}

This was carried out by 20 semi-trained panelists using a 9-point Hedonic scale; where 1 =dislike extremely and 7 =like extremely as described by Lawless and Heyman (2010).

\section{Statistical Analysis}

Analysis of Variance (ANOVA) was used to analyzed all data while significant difference $(p<0.05)$ among the means was determined using Least Significant Difference (LSD) of Statistical Package for Social Science (SPSS) version 16.0. 


\section{RESULTS AND DISCUSSION}

\section{Physicochemical Properties Chemical}

The moisture contents of the samples varied significantly $(p<0.05)$. For samples stored in plastic and low-density polyethylene bags respectively, values of $60.5-90.6 \%$ and $60.4-92.4 \%$ for (Day 4 ) and $60.5-90.7 \%$ and 60.9 - $92.6 \%$ for (Day 7 ) were obtained as compared to (Day 0 ) with a value range of $60.4-90.5 \%$. There was a slight increase in the moisture content during storage with the control having the highest moisture content and the paste treated with $10 \%$ p.t.s having the lowest. The moisture content of the samples stored in low-density polythene was greater than the samples stored in plastic container. Nonetheless, the increase in the moisture content of tomato paste with Pleurotus tuberregium sclerotium flour packaged in both materials is still within the limit (90.63\%) for longer shelf-life as reported by Abdulsalam (2012). It is noteworthy in this study that inclusion of Pleurotus tuberregium sclerotium significantly reduced the moisture content of samples which may be an advantage in terms of preservation and microbial storage (Balogun et al., 2012).

The $\mathrm{pH}$ values of samples with Pleurotus tuberregium sclerotium were generally lower than the sample with no P.t.s giving an indication that supplemented samples were more acidic. The $\mathrm{pH}$ value decreased in both packaging materials on addition of P.t.s with sample containing $10 \%$ having the least of all values. The pH values decreased from 4.40 to 4.05 (Day 0), 3.90 to 3.80 for (Day 4) and 3.80 to 3.70 (Day 7) for the control sample and sample containing $10 \%$ P.t.s stored in plastic container. Similarly, samples stored in low-density polythene had values decreasing from 4.40 to 4.05 (Day 0), 3.95 to 3.50 (Day 4) and 3.80 to 3.40 (Day 7) for the control sample and sample containing $10 \%$ P.t.s, respectively. However, samples stored in lowdensity polyethylene had lower $\mathrm{pH}$ values. Total titratable acidity (TTA) increased within the storage period for all samples stored in plastic container and low-density polythene packaging materials compared to value obtained for DAY 0. This result is in line with the work of Joseph et al. (2015), who reported an increase in TTA of tomato paste treated with oil and citric acid and stored in low-density polyethylene and plastic containers. The general decrease in the $\mathrm{pH}$ and correlating increase in TTA values as the storage time increased might be due to increase in microbial activities, biochemical activities and chemical reaction with storage time (Campos et al., (2006); Okanlawon et al., (2002).

Though the viscosities of the samples decreased significantly $(p<0.05)$ in all the samples with storage time, that of the samples stored in low-density polyethylene was higher than the samples stored in plastic containers. The 
sample treated with $10 \%$ P.t,s (CTX) had the highest viscosity throughout the storage period, which may be attributed to the addition of P.t.s flour to the paste. P.t.s flour has been reported as a thickener in traditional soups preparation (Gbolagade et al., 2006). Since the viscosity of tomato paste depends on the pectin, total soluble solids and size distribution of insoluble constituents (Joseph et al., 2015), this shows that P.t.s has conferred some of these properties on the samples as confirmed in this study.

There was generally a slight decrease in the vitamins $C$ and $A$ contents of the samples in both plastic containers during storage (Table 2). Vitamins $C$ values ranging from $43.6 \mathrm{mg} / \mathrm{g}$ to $44.6 \mathrm{mg} / \mathrm{g}$ and $43.5 \mathrm{mg} / \mathrm{g}$ to $44.6 \mathrm{mg} / \mathrm{g}$ were obtained for samples stored in plastic and low-density polythene, respectively. Sample treated with $10 \%$ P.t.s, had the highest Vitamin A content. Samples stored in plastic container gave generally higher values. This result agrees with the previous work of Joseph et al. (2015) who reported that Vitamin A and C losses may occur under storage conditions due to degradation by light and heat in the storage environment. Rai et al. (2012) also reported that ascorbic acid content of tomatoes decreases during storage at ambient temperature. In addition, the lower permeability of plastic container compared with low-density polythene could have helped reduce the microbial population that would otherwise cause alteration in the nutritive values (Okorie et al, 2004; Guine et al., 2007).

\section{Antioxidant Activity}

There were significant differences $(p<0.05)$ in the antioxidant activity of tomato paste samples during the storage period at 20,40,60, 80 and $100 \mathrm{mg} / \mathrm{ml}(\%)$ inhibition level $\mathrm{mg} / \mathrm{ml}$ (Figure 2). There was a progressive increase in the antioxidant activity of tomato paste samples treated with p.t.s in plastic containers and low-density polythene during storage. Treated pastes packaged in plastic containers showed greater activity than the samples packaged in low-density polythene. At $100 \mathrm{mg} / \mathrm{ml}$ titration, the value range of 48.7-49.9\%, 50.7-53.8\% and 50.0-52.2\%, was obtained for Day 0, Day 4 and Day7 for samples stored in plastic containers, respectively. The value range of $48.7-49.9 \%, 50.3-52.4 \%$ and $49.8-51.9 \%$, was obtained for Day 0, Day 4, and Day 7 for samples stored in low-density polyethylene respectively. The sample with $10 \%$ p.t.s recorded the highest values while the control had the lowest values during storage.

The increase in the antioxidant activity of the treated tomato paste could be due to the addition of Pleurotus tuberregium since it could serve as an alternative source of antioxidants with no side effects (Oranusi et al., 2014). However, there was a slight decrease in the antioxidant activity on the 7th day of storage. Antioxidants present in tomato and Pleurotus tuberregium sclerotium are compounds that inhibit oxidation (Eunok and David, 2009; Toor 
and Savage, 2004; Oyetayo, 2011). Dietary intake of antioxidants found in tomato and tomato products such as carotenoids and flavonoids help to decrease risk of chronic disease, such as breast cancer and prostate and cardiovascular diseases (Agarwal and Rao, 2000).

\section{Microbial Stability}

Values obtained for microbial count (bacterial and fungal) revealed that there was an increase in the bacterial count and fungal count of the samples stored in plastic containers and low-density polythene in (DAY 0) to (DAY 7). However, there was a decrease in the fungal count of the samples treated with $5 \%$ and $10 \%$ Pleurotus tuberregium sclerotium compared to the control sample in both packaging materials during and after storage. The trend observed in the low-density polyethylene stored samples could be because of higher permeability of $\mathrm{O}_{2}, \mathrm{CO}_{2}$, $\mathrm{pH}$ and other gases (Joseph et al., 2015).

Pleurotus tuberregium sclerotium had some effect on microorganisms as shown in Figure 1. Increase in bacterial count compared to the control sample during storage for all samples could be possibly due to the Pleurotus tuberregium sclerotium not being effective against the bacterial strains in the samples, since identification of bacteria present was not done. In addition, the medium or storage temperature may support the growth of the kind of bacteria present. Increase in the fungal count but lower compared to the control sample might be due to the bioactive compound present in the Pleurotus tuberregium sclerotium. Contamination of the sclerotium powder cannot be ruled out as a possible reason for the increased bacterial count as stated by Oranusi et al., (2014). The moisture level and rich chemical composition of the sclerotium also dictates the associated bacteria and fungi that will have favorable environment to proliferate. This could have contributed to the associated microflora in the tomato paste.

\section{Sensory Evaluation}

The sensory evaluation of samples revealed that all the samples were acceptable in terms of aroma, taste and after-taste as assessed by the panelists (Table 3). The control sample had the highest value of (8.03) for overall acceptability while sample containing $10 \%$ P.t.s had the lowest value of (5.13). The control sample was the most preferred which was followed by the sample with $5 \%$ Pleurotus tuberregium sclerotium. On the whole, all the samples were scored favourably in terms of their sensory characteristics. Sensory evaluation is an important tool to assess the acceptability of new food products by consumers (Kolawole et al., 2013). 


\section{CONCLUSION}

Pleurotus tuberregium sclerotium flour improved the physicochemical properties and antioxidant activity of tomato paste. There was a decrease in the fungal load but not in the bacterial content of the samples; further studies may be required on this aspect. The samples with highest concentration of Pleurotus tuberregium performed better in all cases studied. Also, the samples stored in plastic container gave improved results compared to those stored in low-density polyethylene in terms of ascorbic acid retention and microbial stability during storage. Thus, the addition of Pleurotus tuberregium sclerotium flour would be effective in improving the physicochemical properties, micronutrient content and antioxidant activity of tomato paste with acceptable sensory properties.

Table 1: Moisture content and viscosity of stored tomato paste samples

\begin{tabular}{|c|c|c|c|}
\hline SAMPLE & DAY 0 & DAY 4 & DAY 7 \\
\hline \multicolumn{4}{|l|}{$\begin{array}{l}\text { Moisture } \\
\text { content } \\
(\%)\end{array}$} \\
\hline XCT A & $90.51^{a} \pm 0.014$ & $90.61^{a} \pm 0.028$ & $90.67^{a} \pm 0.014$ \\
\hline TCX A & $62.28^{b} \pm 0.049$ & $64.54^{b} \pm 0.014$ & $64.67^{b} \pm 0.014$ \\
\hline CTX A & $60.42^{\mathrm{c}} \pm 0.028$ & $60.48^{\mathrm{c}} \pm 0.014$ & $60.53^{c} \pm 0.014$ \\
\hline XCT B & $90.51^{a} \pm 0.014$ & $92.39^{a} \pm 0.071$ & $92.59^{\mathrm{a}} \pm 0.014$ \\
\hline TCX B & $62.28^{b} \pm 0.049$ & $64.79^{b} \pm 0.042$ & $64.89^{b} \pm 0.035$ \\
\hline CTX B & $60.42^{c} \pm 0.028$ & $60.44^{\mathrm{c}} \pm 0.030$ & $60.86^{c} \pm 0.021$ \\
\hline \multicolumn{4}{|l|}{ Viscosity } \\
\hline XCT A & $44.5^{a} \pm 0.014$ & $43.7^{c} \pm 0.000$ & $43.6^{b c} \pm 0.000$ \\
\hline TCX A & $44.6^{a} \pm 0.014$ & $43.9^{b} \pm 0.000$ & $43.8^{b} \pm 0.014$ \\
\hline CTX A & $44.6^{a} \pm 0.007$ & $44.1^{\mathrm{a}} \pm 0.057$ & $44.1^{\mathrm{a}} \pm 0.014$ \\
\hline XCT B & $44.5^{a} \pm 0.014$ & $43.6^{\mathrm{bc}} \pm 0.007$ & $43.5^{c} \pm 0.014$ \\
\hline TCX B & $44.6^{a} \pm 0.014$ & $43.8^{b} \pm 0.007$ & $43.6^{b c} \pm 0.000$ \\
\hline CTX B & $44.6^{a} \pm 0.007$ & $43.9^{b} \pm 0.007$ & $43.8^{b} \pm 0.007$ \\
\hline
\end{tabular}

The values in the same column with different superscript are significantly different $(p<0.05)$. Values are means of duplicate determination.

Key; XCT is the control; $100 \%$ tomato paste and $0 \%$ Pleurotus tuberregium sclerotium. TCX: $95 \%$ tomato paste and $5 \%$ Pleurotus tuberregium sclerotium and CTX: $90 \%$ tomato paste and $10 \%$ Pleurotus tuberregium sclerotium. A: Plastic container B: low density polythene. 0, 4 and 7 indicates Day 0, Day 4 and Day 7 respectively. 
Table 2: Ascorbic acid $(\mathrm{mg} / \mathrm{g})$ and Vitamin A $(\mu \mathrm{g} / \mathrm{g})$ content of stored tomato samples

\begin{tabular}{|c|c|c|c|}
\hline SAMPLE & DAY 0 & DAY 4 & DAY 7 \\
\hline $\begin{array}{l}\text { Ascorbic acid } \\
(\mathrm{mg} / \mathrm{g})\end{array}$ & & & \\
\hline XCT A & $44.5^{b} \pm 0.014$ & $43.7^{c} \pm 0.000$ & $43.6^{b} \pm 0.000$ \\
\hline TCX A & $44.6^{a} \pm 0.014$ & $43.9^{b} \pm 0.000$ & $43.8^{b} \pm 0.014$ \\
\hline CTX A & $44.6^{a} \pm 0.007$ & $44.1^{\mathrm{a}} \pm 0.057$ & $44.1^{\mathrm{a}} \pm 0.014$ \\
\hline ХСТ B & $44.5^{b} \pm 0.014$ & $43.6^{c} \pm 0.007$ & $43.5^{\mathrm{c}} \pm 0.014$ \\
\hline TCX B & $44.6^{\mathrm{a}} \pm 0.014$ & $43.8^{b} \pm 0.007$ & $43.6^{b} \pm 0.000$ \\
\hline CTX B & $44.6^{a} \pm 0.007$ & $43.9^{\mathrm{a}} \pm 0.007$ & $43.8^{a} \pm 0.007$ \\
\hline \multicolumn{4}{|c|}{ Vitamin A $(\mu \mathrm{g} / \mathrm{g})$} \\
\hline XCT A & $55.61^{c} \pm 0.014$ & $55.30^{\circ} \pm 0.021$ & $55.24^{\mathrm{c}} \pm 0.014$ \\
\hline TCX A & $55.65^{b} \pm 0.007$ & $55.59^{b} \pm 0.007$ & $55.57^{b} \pm 0.000$ \\
\hline CTX A & $55.71^{\mathrm{a}} \pm 0.014$ & $55.67^{a} \pm 0.028$ & $55.66^{\mathrm{a}} \pm 0.014$ \\
\hline XCT B & $55.61^{\mathrm{c}} \pm 0.014$ & $55.09^{c} \pm 0.014$ & \\
\hline & & & $55.04^{c} \pm 0.057$ \\
\hline TCX B & $55.65^{b} \pm 0.007$ & $55.52^{b} \pm 0.035$ & $55.51^{\mathrm{b}} \pm 0.007$ \\
\hline СТX B & $55.71^{a} \pm 0.014$ & $55.62^{\mathrm{a}} \pm 0.028$ & $55.62^{a} \pm 0.000$ \\
\hline
\end{tabular}

The values in the same column with different superscript are significantly different $(p<0.05)$. Values are means of duplicate determination.

Key; XCT is the control; $100 \%$ tomato paste and $0 \%$ Pleurotus tuberregium sclerotium, TCX: 95\% tomato paste and 5\% Pleurotus tuberregium sclerotium, CTX: $90 \%$ tomato paste and 10\% Pleurotus tuberregium sclerotium. A: Plastic container, B: low density polythene. 0,4 and 7 indicates Day 0, Day 4 and Day 7 respectively. 
Table 3: Sensory evaluation of treated tomato paste

\begin{tabular}{llllllll|}
\hline SAMPLE & APPEARANCE & COLOR & AROMA & TASTE & AFTERTASTE & OVERALLACC \\
\hline XCT & $8.23^{\mathrm{a}} \pm 0.63$ & $8.20^{\mathrm{a}} \pm 0.61$ & $7.40^{\mathrm{a}} \pm 1.04$ & $7.37^{\mathrm{a}} \pm 0.89$ & $7.07^{\mathrm{a}} \pm 0.94$ & $8.03^{\mathrm{a}} \pm 0.56$ \\
\hline TCX & $6.20^{\mathrm{b}} \pm 1.24$ & $6.17^{\mathrm{b}} \pm 1.05$ & $6.87^{\mathrm{ab}} \pm 1.07$ & $6.10^{\mathrm{b}} \pm 1.19$ & $5.83^{\mathrm{b}} \pm 1.23$ & $6.33^{\mathrm{b}} \pm 1.27$ \\
\hline CTX & $4.77^{\mathrm{c}} \pm 1.43$ & $4.60^{\mathrm{c}} \pm 1.43$ & $6.33^{\mathrm{b}} \pm 1.27$ & $5.17^{\mathrm{b}} \pm 1.18$ & $5.20^{\mathrm{b}} \pm 1.56$ & $5.13^{\mathrm{a}} \pm 1.53$ \\
\hline
\end{tabular}

The values in the same column with different superscript are significantly different $(p<0.05)$. Values are means of duplicate determination.

Key; XCT is the control; $100 \%$ tomato paste and $0 \%$ Pleurotus tuberregium sclerotium, TCX: 95\% tomato paste and 5\% Pleurotus tuberregium sclerotium, CTX: $90 \%$ tomato paste and 10\% Pleurotus tuberregium sclerotium. A: Plastic container, B: low density polythene. 0,4 and 7 indicates Day 0, Day 4 and Day 7 respectively

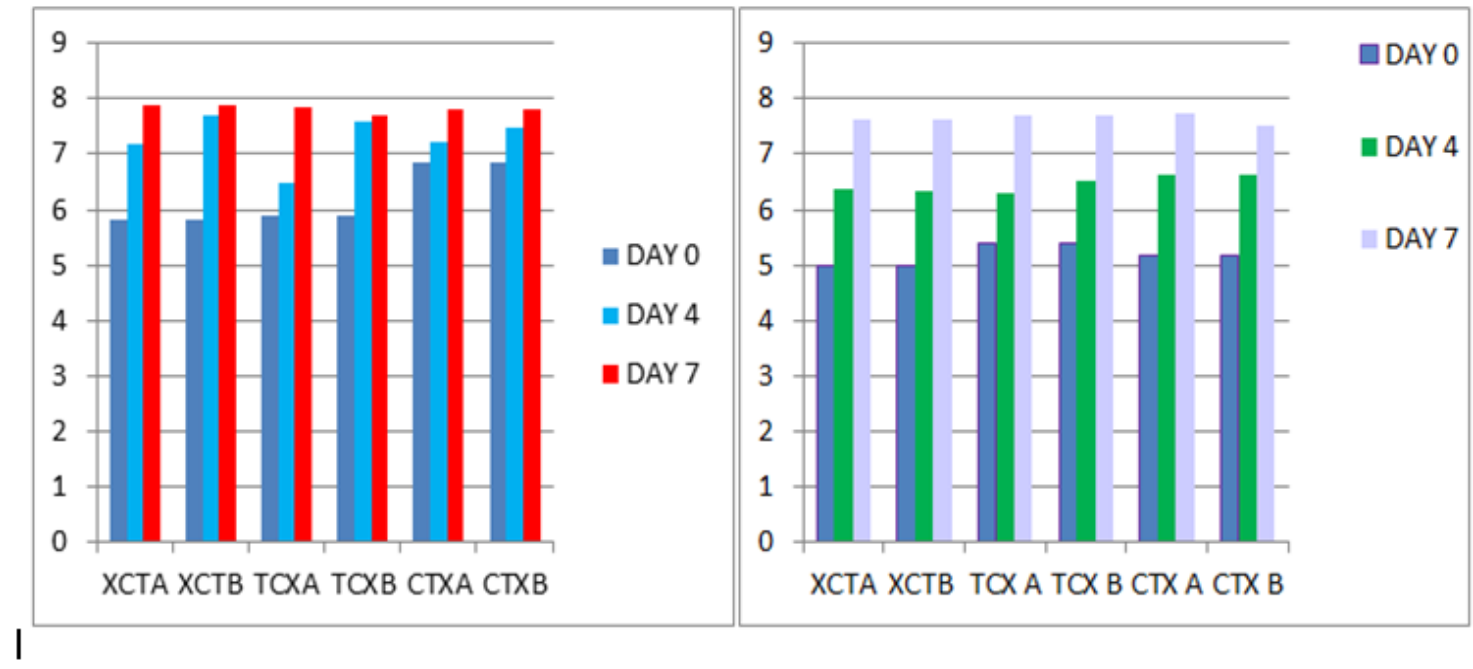
a. Fungal count
b. Bacterial count

Figure 1: Fungal and microbial count of tomato paste treated with Pleurotus tuberregium sclerotium flour 


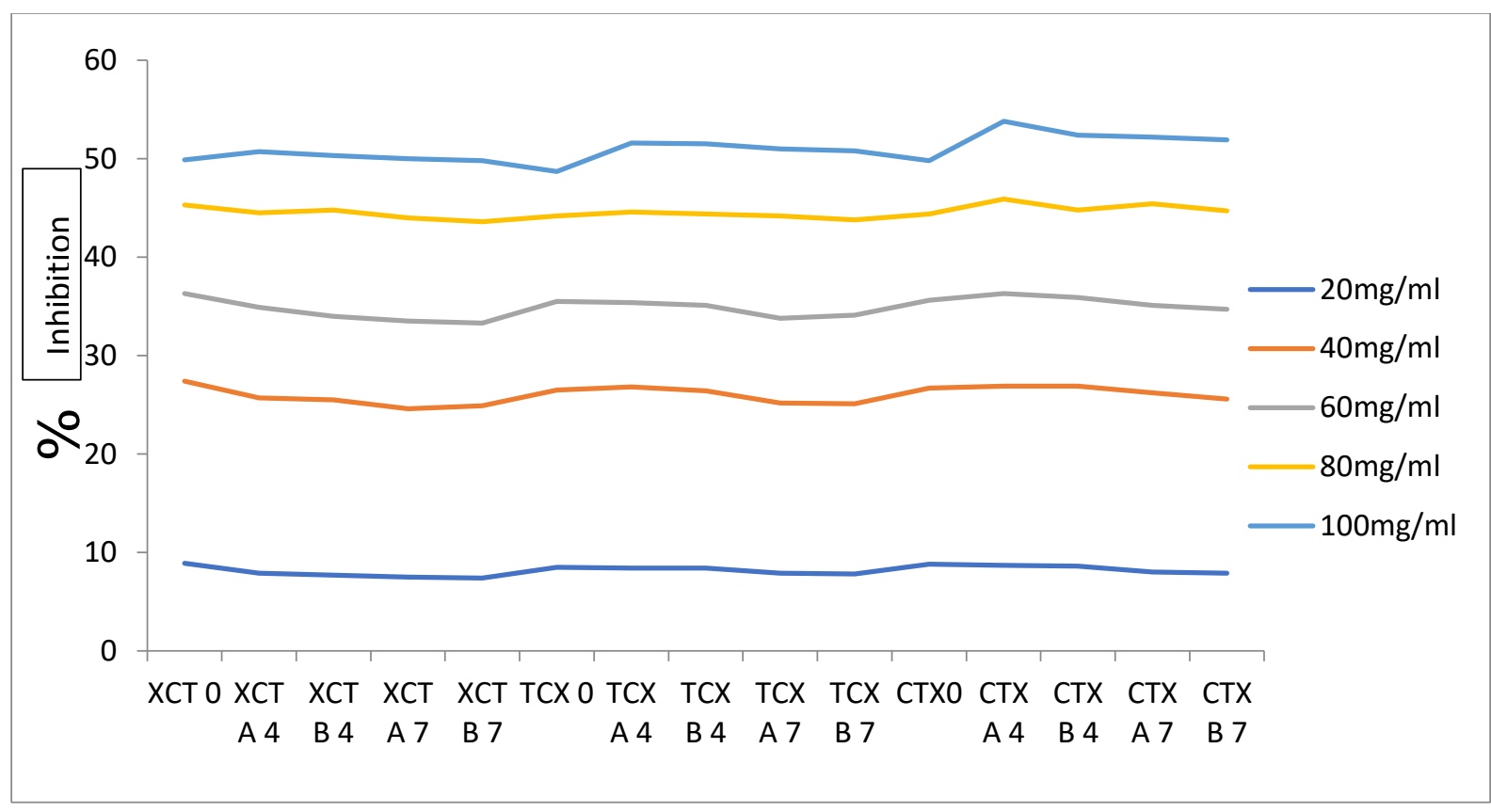

Figure 2: Antioxidant activity of tomato paste samples

\section{REFERENCES}

Association of Official Analytical Chemist (A.O.A.C.) (1990). Official methods of Analysis (15th ed.), Association of Official Analytical Chemist, Washington, D.C. USA.

Abdulsalam, S. (2012). Effect of moisture content on the preservation of chemically pretreated canned tomato paste. Arid Zone Journal of Engineering, Technology and Environment, 8, 87-94.

Agarwal, S. and Rao, A.V. (2000). Carotenoids and Chronic Diseases. Drug Metab Drug Interact, 17(1-4), 189-210.

Anyanwu, N.G., Mboto, C.I., Solomon, L. and Frank-Peterside, N. (2016). Phytochemical, Proximate Composition and Antimicrobial Potentials of Pleurotus Tuberregium Sclerotium. New York Science Journal, 9, 1, 35-42.

Balogun, M.A., Karim, O.R., Kolawole, F.L. and Solarin, A.O. (2012): Quality Attributes of Tapioca Meal Fortified with Defatted Soy Flour. Agrosearch 12 (1); 59 -65.

Balogun, M.A., Arise, A.K., Arise, R.O, Kolawole, F. L. and Oyebanji, O.O (2015): Effect of Addition of Moringa Oleifera leaf on the Nutritional Quality, Microbial and Sensory Properties of Spices. Croatian Journal of Food Technology, Biotechnology \& Nutrition. 11 (3 - 4), 91 - 94. 
Campos, C. A. B., Fernandes, P. D., Gheyi, H. R., Bianco, F.F., Goncalves, C. B. and Campos, S. A. F. (2006). Yield and fruit quality of industrial tomato under saline irrigation. Scientia Agricola, 63(2), 146-152.

Correia, A. F. K., Loro, A. C., Zanatta, S., Spoto, M. H. F. and Vieira, T. M. F. S. (2015). Effect of Temperature, Time, and Material Thickness on the Dehydration Process of Tomato. International Journal of Food Science, 1-7. http://dx.doi.org/10.1155/2015/970724

Eunok, C. and David B.M. (2009). Mechanisms of Antioxidants in the Oxidation of Foods. Comprehensive Reviews in Food science and Food safety, 8, 345-358.

Gbolagade, J. S., and Fasidi I. O. (2006). Antimicrobial activities of some selected Nigeria mushroom. African journal of Biomedical Research, 8, 83-87.

Guine, R.P.F., Ferreira, D.M.S., Barroca, M.J. and Goncalves, F.M. (2007). Influence of Drying Method on Some Physical and Chemical Properties of Pears. International Journal of Fruit Science, 7, 101-118.

Ikewuchi, C. C. and Ikewuchi, C. J. (2010). Nutrient Composition of Pleurotus tuberregium (FR) Sings Sclerotia. Global journal of pure and applied Sciences, 17, 51-54.

Iwe, M. O. (2002). Handbook of sensory Methods and Analysis, Rejoint Com. Services. Ltd, 76-77.

Iwuagwu, M. A. and Onyekweli, A. O. (2002). Preliminary investigation into the use of Pleurotus tuber-regium powder as a tablet disintegrant. Tropical Journal Pharmaceutical Research, 1, 29-37.

Joseph, A., Agomuo, J. K., Alaka, I. C. and Faasema, J. (2015). Storage storability of tomato paste as influenced by oil-citric and packaging materials. African Journal of Food Science, 9, 120-125.

Kolawole, F.L., Balogun, M.A., Opaleke, D.O. and Amali, H.E. (2013). An Evaluation of Nutritional and Sensory Qualities of Wheat Moringa Cake. Agrosearch, 13 (1), 87 - 93.

Lawless, H. T. and Heymann, H. (2003). Sensory Evaluations of Food: Principle and Practices Springer, New York, USA.

Liyana-Pathiraman, C.M. and Shahidi, F. (2005). Antioxidant activity of commercial soft and hard wheat (Triticum aestivum $\mathrm{L}$ ) as affected by gastric pH condition. Journal of Agricultural Food Chemistry, 53, 2433-2440.

Okanlawon, S.O., Ibrahim, M.H. and Oyebanji, A.O. (2002). Effect of predrying treatment on the storage of dried tomatoes. Tropical Science, 42(1), 40-41. 
Okorie, S.U., Nwanekezi, E.C. and Okoro, C.C (2004). The Quality properties of Tomatoes as influenced by processing with a chemical preservative and storage. Nigerian Food Journal, 22, 195-197.

Oranusi, U. S., Ndukwe, C. U. and Braide, W. (2014). Production of Pleurotus tuberregium (Fr.) Sing Agar, chemical composition and microflora associated with sclerotium. International Journal of Current Microbiology and Applied sciences, 3, 115-126.

Oyetayo, V. O. (2011). Medicinal uses of mushroom in Nigeria: Towards full and sustainable exploitation. African Journal of Traditional Complementary and Alternative Medicines, 8, 3-7.

Rai, G.K., Kumar, R., Singh, A.K., Rai, P.K., Rai, M., Chaturvedi, A.K. and Rai, A.B. (2012). Changes in Antioxidant and Phytochemical Properties of Tomato (Lycopersicon Esculentum Mill) under Ambient Condition. Pakistan Journal of Botany, 44(2), 667-670.

Silva-Beltrán, N. P., Ruiz-Cruz, S., Cira-Chávez, L. A., Estrada-Alvarado, M. I., Ornelas-Paz, J. d. J., López-Mata, M. A., Del-Toro-Sánchez, C. L., Ayala-Zavala, J. F., \& Márquez-Ríos, E. (2015). Total phenolic, flavonoid, tomatine, and tomatidine contents and antioxidant and antimicrobial activities of extracts of tomato plant. International Journal of Analytical Chemistry, 2015, 1-10, http://dx.doi.org/10.1155/2015/284071.

Turkoglu, S. (2007). Genotoxicity of five food preservatives tested on root tips of Alliumcepa L. Mutation Research, 626, 4-14. 